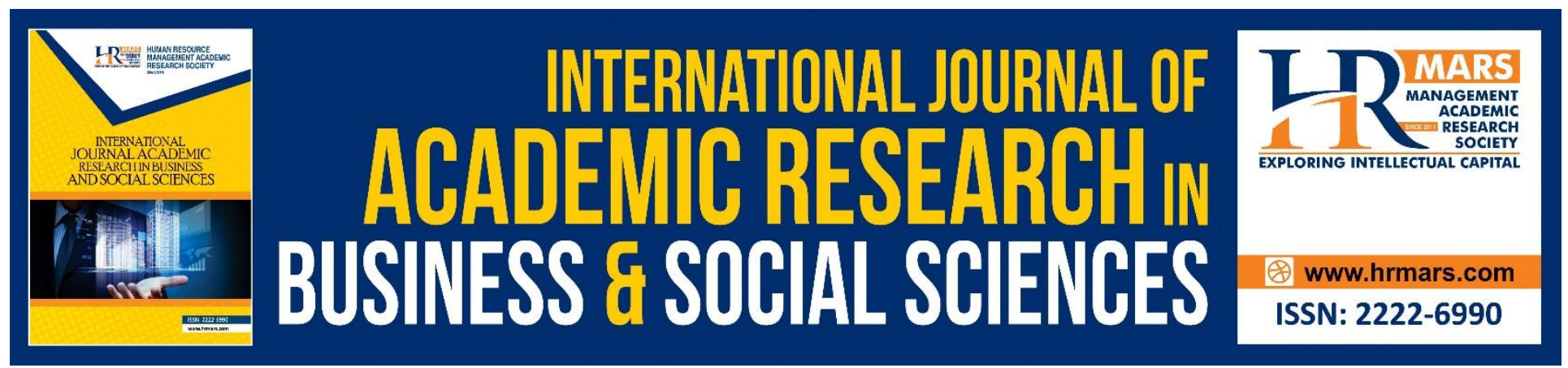

\title{
HRM Practices Employee Engagement and Teachers Turnover Intentions: A Cross- Sectional Study from Public Secondary Schools in Kenya.
}

Onesmus M. Kamau, Stephen M. A. Muathe, Lawrence Wainaina

To Link this Article: http://dx.doi.org/10.6007/IJARBSS/v10-i9/7726

DOI:10.6007/IJARBSS/v10-i9/7726

Received: 01 June 2020, Revised: 03 July 2020, Accepted: 09 August 2020

Published Online: 19 September 2020

In-Text Citation: (Kamau, Muathe, \& Wainaina, 2020)

To Cite this Article: Kamau, O. M., Muathe, S. M. A., \& Wainaina, L. (2020). HRM Practices Employee Engagement and Teachers Turnover Intentions: A Cross- Sectional Study from Public Secondary Schools in Kenya. International Journal of Academic Research in Business and Social Sciences, 10(9), 257-271.

Copyright: (c) 2020 The Author(s)

Published by Human Resource Management Academic Research Society (www.hrmars.com)

This article is published under the Creative Commons Attribution (CC BY 4.0) license. Anyone may reproduce, distribute, translate and create derivative works of this article (for both commercial and non-commercial purposes), subject to full attribution to the original publication and authors. The full terms of this license may be seen

at: http://creativecommons.org/licences/by/4.0/legalcode

Vol. 10, No. 9, 2020, Pg. 257 - 271

http://hrmars.com/index.php/pages/detail/IJARBSS

JOURNAL HOMEPAGE

Full Terms \& Conditions of access and use can be found at http://hrmars.com/index.php/pages/detail/publication-ethics 


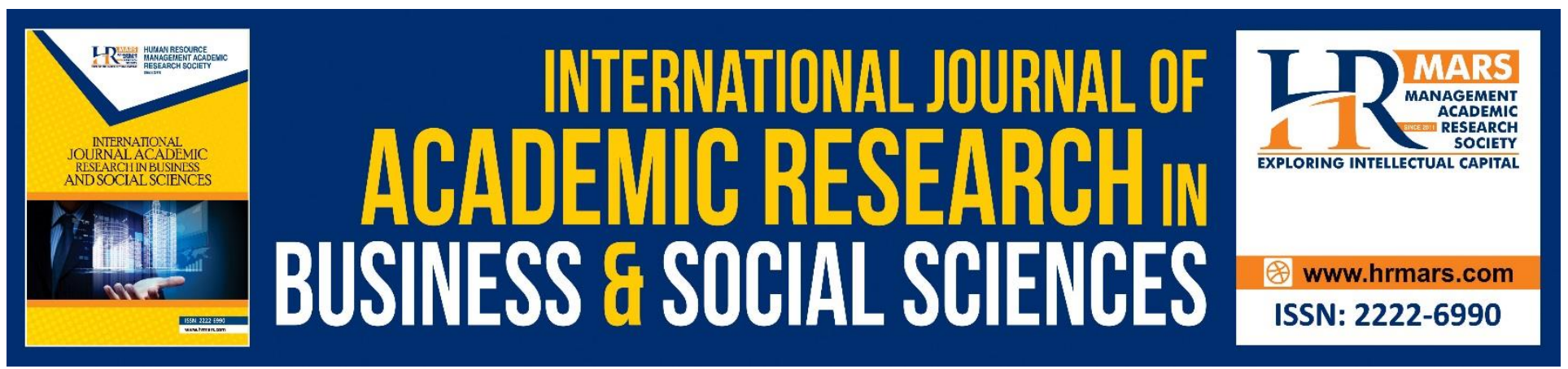

\title{
HRM Practices Employee Engagement and Teachers Turnover Intentions: A Cross- Sectional Study from Public Secondary Schools in Kenya.
}

\author{
Onesmus M. Kamau, Stephen M. A. Muathe, Lawrence Wainaina \\ School of Business, Kenyatta University, Kenya \\ Email: mwankiro04@gmail.com, muathesm@yahoo.com, Iwarwimbo@yahoo.com
}

\section{Abstract}

Employees play a key role in achievement of organizations' objectives and thus every organization endeavours to ensure employee retention. However as the organizations seek to do this they are faced with the challenge of low employees' engagement and turnover intentions. Although it has been suggested that Human Resource Management (HRM) practices may affect employees' engagement and turnover intentions, empirical evidence in Kenyan context is scanty. The study thus sought to investigate the mediating effect of employee engagement in the relationship between HRM practices and turnover intentions of teachers in public secondary schools in Murang'a county Kenya. The study was guided by the Social Exchange Theory (SET). The target population was 3752 Teachers Service Commission (TSC) teachers in 304 public secondary schools in Murang'a county Kenya. The study used multi stage random method to select a sample size of 400 teachers from 40 schools. A self-administered semi-structured questionnaire was used to collect data. The quantitative data was analyzed using descriptive and inferential statistics of binary logistic regression. The findings of the study indicated that employee engagement partially mediates the relationship between HRM Practices and turnover intentions of teachers in public secondary schools in Murang'a County Kenya. Policy implications of study findings have been discussed.

Keywords: Human Resource Practices, Employee Engagement, Public Secondary Schools, Turnover Intentions, Teachers, Kenya.

\section{Introduction}

Education in any country plays an important role of fostering development and well-being of the citizens. To achieve this role teachers are key since they support the learning process and inculcation of acceptable behavior among students. In playing this role, the result is improvement in quality of life, which benefits both the individual and the society as a whole. However realization of these positive outcomes can be hampered by teachers' turnover since teacher turnover compromises the 
INTERNATIONAL JOURNAL OF ACADEMIC RESEARCH IN BUSINESS AND SOCIAL SCIENCES Vol. 10, No. 9, 2020, E-ISSN: 2222-6990 @ 2020 HRMARS

teaching and learning process by diverting resources from the classroom (Allensworth, Penscia and Mazenzo, 2009).

Teacher turnover has been described as a global challenge and a situation that is complex and has been frequently suggested to be either caused by problem with workforce planning, or as an indicator of lack of teacher morale and motivation (Waititu, 2013). According to Kaur, Mohindru and Pankaj (2013) employees would leave organizations due to a number of reasons such as lack of job satisfaction, not satisfied with the employer, inadequate promotion and growth opportunities, and availability of greener pastures outside among others.

Turnover intentions as opposed to real turnover has continued to be used in studies to predict turnover in organization because of the ease to measure turnover intentions as opposed to real turnover which may be difficult due to lack of data on employees of who have actually left (Verhees, 2012) and also because of its ability to predict actual turnover (Bhat, 2014). Park and Kim (2009) asserts in the decision-making process of the employees turnover intentions constitute the final cognitive step whereby an employee actively opts to quit and starts looking for employment elsewhere. They further stated that employee intentions to quit the current job starts with mere thoughts and then statements by the employee that he/she desires to leave the employer. According to Currie and Hill ( 2012) turnover intentions just like actual turnover manifests itself in two ways; first, an employee (teacher) intention to leave the employer within the same profession and second, an employee (teacher) intention to change the profession altogether.

Perez (2008) posits that although measurements of actual turnover and turnover intentions have been done separately, it is expected that as the intention to leave increases, actual turnover would increase. Park and Kim (2009) assert that employee turnover intentions is usually the last step in employee decision process before quitting his or her job. Thus turnover intention is usually considered as the last signal to quitting a job. Previous studies have tested turnover intentions as a continuous variable however, the current study considered turnover intentions as a dichotomous variable thus applied logistic regression in the analysis.

The government of Kenya through TSC in its endeavour to make teaching attractive and also to ensure teachers retention, has developed various policies. Besides these policies, the TSC has also delocalize some of the Human resource functions to the counties thus bringing them closer to teachers (Manthi, Kilika \& Kimencu, 2018). Despite the Government intervention through various policies the problem of teacher turnover intentions still exists.

Just like actual turnover intentions (intention to leave) has negative effects for instance, Chughtai (2013) asserts that when employees have thoughts of quitting it affects their loyalty to the organization and it may finally lead to the actual quitting of the valuable employee. In addition, Tarmizi (2008) posits that intention to leave also affects other employees as it reduces their commitment within the organization. Krishan and Sigh (2010) also assert that teachers' turnover intention (intention to leave) leads to reduced motivation hence hindering achievement of schools goals. It is therefore important to enhance teachers' retention by reducing intention to leave so as to improve teaching and learning processes in schools.

It has been suggested that proper implementation of HRM practices can lead to reduction of intention to leave of employees. According to Armstrong and Stephen (2014) it is important for an organization to be consistent in implementing HRM practices since it provides proof to employees that the organization is concerned about them. On the other hand Kinnie, Hutchinson, Purcell, Rayton and Swart (2005) opined that, employees attitudes tend to be less affected by the way the practices 
INTERNATIONAL JOURNAL OF ACADEMIC RESEARCH IN BUSINESS AND SOCIAL SCIENCES Vol. 10, No. 9, 2020, E-ISSN: 2222-6990 @ 2020 HRMARS

are implemented but by how on a daily basis managers implement. Thus how HRM practices are operationalized tends to affect employees attitude towards the organization and consequently their turnover intentions.

It is also worth noting that despite the direct relationship between HRM practices and turnover intentions, other factors may also mediate the relationship. According to SET employees reciprocate to the organization when they are provided with resources such as decent pay, opportunities for development, through positive behavior such as engagement and low intention to leave (Eisenberger, Huntington, Hutchinson, \& Sowa, 1986). However the mediating role of employee engagement has not been fully explored particularly among teachers in Kenya. The studies that have been able to confirm the mediating role of employee engagement and turnover intentions have mostly been carried out in other countries (Hakanen, Bakker \& Schaufeli, 2006; Schaufeli \& Salonova, 2008; Chughtai, 2013). It is therefore necessary to further explore the mediating role of employee engagement in the relationship between HRM practices and turnover intentions in a different context and this is what this study sought to explore.

\section{Employee Engagement}

Shuck and Wollard (2009) in their conceptualization of employee engagement argue that it can be defined as a working condition that is manifested through one giving oneself wholly towards achievement of organizational outcomes. According to these authors, employee engagement has no physical properties but is manifested and often measured behaviorally.

The benefits of employee engagement to organizations have been documented by several authors. Saks (2006) posits that more engaged employees would remain committed and thus stick longer with the organization. Koyuncu, Burke and Fiksenbaum (2006) also assert that engaged employees highly identifies with a job in a way that makes an employee unwilling to leave their current jobs. Stairs and Galpin (2010) suggested that where employees are highly engaged it would lead to lower absenteeism and higher employee retention; increased employee effort and productivity among others.

Lockwood (2007) also posits that intention to leave among employees who are engaged would be less since they love their work. Banken (2010) on the other hand posit that the reason why employee engagement has drawn a lot of attention is because of positive consequences to organizations. The author further asserts that since engagement is an individual-level construct one should anticipate individuals' attitudes, intentions, and behaviors to relate to engagement.

It is therefore necessary for any firm that wants to retain its valuable employees to identity what can promote engagement among its employees. Chughtai (2013) suggests that the effective application of HRM practices will foster employee engagement and would result to high motivation, output and retention. Therefore in this study, employee engagement was conceptualized as a mediator in the relationship between HRM practices and turnover intentions and was measured in terms of discretionary effort and motivation.

\section{Objectives of the Study}

This study was guided by the following objectives:

- To find out the effect of HRM practices on turnover intentions of teachers in public secondary schools in Murang'a county Kenya 
INTERNATIONAL JOURNAL OF ACADEMIC RESEARCH IN BUSINESS AND SOCIAL SCIENCES Vol. 10, No. 9, 2020, E-ISSN: 2222-6990 @ 2020 HRMARS

- To establish the mediating effect of employee engagement in the relationship between HRM practices and turnover intentions of teachers in public secondary schools in Murang'a county Kenya.

\section{Review of Literature \\ Theoretical Review}

This study was grounded under the Social Exchange Theory (SET), which stipulates that parties that are in a situation that they are reciprocally depended on each other generate obligations through a series of interactions (Kular, Gatenby, Rees, Soane, \& Truss, 2008). SET is built on the principle that in organizations, relationships advance with time through trust, loyalty and mutual commitments so long as the rules of exchange are respected (Crospranzano \& Mitchel, 2005). Thus by abiding to these rules each party feels obligated to each other.

From the SET perspective employees tend to examine the quality of their relationship with their organization and when they find presence of quality relationship, they get motivated. Social relationship are based on sense of reciprocity between the parties involved such that individuals have expectations from the organization which may include fair and adequate rewards, career opportunities, job security, and emotional support (Eisenberger et al., 1986). Therefore, if these employees' expectations are met by an organization it is reciprocated through increased intention to stay.

Saks (2006) suggests that engagement is another way through which individuals tend to reciprocate positively to the organization. That is resources received by employees from the organization determines employees' engagement levels. That is, in line with HRM practices and turnover intentions relationship, employees will reciprocate to the organization through positive behavior when they are satisfied with the HRM practices (Kinnie et al., 2005). This assertion is supported by Schaufeli (2013) who states that when the organization provides to the employees resources such as good pay, recognition, and development opportunities they would reciprocate positively towards the organization. SET is thus applicable in employee engagement studies since it considers reciprocal relationship between employers and employees (Cheche, Muathe \& Maina, 2017).

\section{Empirical Review}

Studies have shown that employee quit their jobs due to low engagement in their jobs. Fleming and Asplund (2007) assert that, engaged employees have emotional, social and even spiritual connection to the organization's mission, vision and purpose and therefore they endeavour to see their organization succeed. This implies that having engaged manpower can be a great advantage to an organization since such employees will never think of leaving the organization but will give their whole towards the success of the firm.

Various studies and literature have considered the mediating role of employee engagement. The studies that have used the JD-R model have shown that employee engagement mediates the relationships considered. A study by Schaufeli and Salanova (2008) carried among the Spanish and Dutch respondents established that work engagement mediated job resources and turnover intentions relationship. This implies that job resources (HRM practices) enhance employee engagement which finally leads to low level of intention to leave. Study by Schaufeli and Bakker, (2004) established employee engagement mediated job resources and organizational outcomes. 
INTERNATIONAL JOURNAL OF ACADEMIC RESEARCH IN BUSINESS AND SOCIAL SCIENCES Vol. 10, No. 9, 2020, E-ISSN: 2222-6990 @ 2020 HRMARS

Other studies that have confirmed the mediating role of employee engagement between job resources and intention to stay are (Hakanen et al., 2006; Llorens, Bakker, Schaufeli \& Salanova, 2006).

Banken (2010) study used a questionnaire to collect data among 454 employees, who worked in different organizations in the Netherlands. The findings indicated employee engagement had a significantly positive effect on turnover intentions and partially mediated the relation between HRM practices and turnover intentions. This study had respondents from different organizations so the findings could be generalized. However, it was in a developed country as opposed to the current study that was in developing country and also used different method of inferential analysis.

Soanne, Truss, Alfes, Shantz, Rees, and Gatenby (2012) did a study on employees working for a retail organization in the United Kingdom. The study found that employee engagement correlated negatively with turnover intentions $(-0.49)$ while regression results indicated employee engagement explained a relatively moderate amount of variance (24\%) in employee turnover intentions. However the study tested direct relationship between employee engagement and turnover intentions but the current study tested the mediating effect of employee engagement. This study also involved retail employees as respondents while for the current study the respondents were teachers.

In the study by Gichohi (2014), engagement mediated the relationship between internal enhancers, leadership and organizational factors and external enhancers among library workers. However, these study variables were different from the current study and the study was among library workers while the current study was among teachers. A Study by Chughtai (2013) also found employee engagement to be a strong mediator in the HRM - turnover intentions relationship. However, the study was carried in a university and not in secondary schools as is the case with the current study.

Though there are previous studies on mediating role of employee engagement, no single study has been identified that has been done in Kenya in relation to turnover intentions of teachers in public secondary schools, and also that used logistic regression. Moreover, literature on HRM practices, engagement and turnover intentions in Kenyan context is limited hence prompting this research. This study therefore sought to establish the role of employee engagement in the HRM, turnover intentions relationship in public secondary schools in Murang'a County Kenya. Based on the theoretical and empirical review the study developed the following hypothesis:

$\mathrm{H}_{0}$ : Employee engagement does not mediate the relationship between HRM practices and turnover intentions of teachers in public secondary schools in Murang'a county Kenya.

\section{Research Methodology}

This study adopted both descriptive and explanatory research design. The use of descriptive design in this study facilitated the researcher to vividly describe the characteristics of the participants and nature of their responses to the research questions (Kothari, 2004). Explanatory design helped to explain how the independent and the dependent variables relate (Firebaugh, 2008).

The target population was 3752 teachers from 304 schools in Murang'a county Kenya. The study thus used multi stage random sampling method to select the 400 teachers from 40 schools in the county. The Yamane (1967) formula was used to obtain a representative sample size of teachers from the County.

$\mathrm{n}=\mathrm{N} \div 1+\mathrm{N}(\mathrm{e} 2) \quad(3752) \div 1+3752(0.052)=400$. Source: Yamane $(1967)$

Where $\mathrm{n}=$ sample size, $\mathrm{N}=$ Entire Population, $\mathrm{e}=$ level of precision: 
INTERNATIONAL JOURNAL OF ACADEMIC RESEARCH IN BUSINESS AND SOCIAL SCIENCES Vol. 10, No. 9, 2020, E-ISSN: 2222-6990 @ 2020 HRMARS

Data from teachers was collected through a self-administered semi- structured questionnaire. The questionnaire was developed from review of previous studies. Reliability of the instrument was ensured by deriving and adopting from the literature those items that other researchers have tested their reliability (Muathe, 2010). Cronbach's alpha correlation that measures internal consistency was also used to determine reliability where items with Cronbach's alpha of 0.7 were considered reliable.

The quantitative data was analyzed using descriptive and inferential statistics. Descriptive statistics were applied to analyze quantitative data in order to generate percentages, means, and standard deviation of both independent, mediating and dependent variables. The dependent variable in this study which was considered a dichotomous binary variable was turnover intentions and was indicated by intention to leave or stay. Therefore, the inferential used was binary logistic regression since it is suitable where one wants to show presence or absence of a particular attribute of interest (Rodriguez, 2007). According to Sweet and Grace-Martin, (2012) logistic regression helps to effectively determine whether an event will occur or not and provides a better choice of describing relationships that involve probability of occurrence of events.

Logistic regression enables inclusion of nonlinear effects and this is why it is preferred to other discrete choices (Press \& Wilson, 2007). Logistic regression was used to determine how well the independent variables in the study predicted the dependent variable turnover intentions. Estimation and test of hypothesis was done at $95 \%$ confidence interval. If the p-value was less than 0.05 the null hypothesis was rejected otherwise it was not rejected.

\section{Findings and Discussion}

A pilot study was carried out to test the reliability of the research instruments. Cronbach alpha correlation was used to determine internal consistency where items with Cronbach's alpha of 0.7 and above were considered reliable. Table 1 shows the results of reliability test.

Table 1: Results of Reliability Test

\begin{tabular}{lccc}
\hline Variables & Number of Items & Cronbach's Alpha & Remarks \\
\hline Compensation & 6 & 0.860 & Scale Reliable \\
Performance Appraisal & 8 & 0.858 & Scale Reliable \\
Career Development & 7 & 0.753 & Scale Reliable \\
Training & 7 & 0.778 & Scale Reliable \\
Employee Engagement & 8 & 0.933 & Scale Reliable \\
Overall Reliability & 36 & 0.792 & Scale Reliable
\end{tabular}

As shown in Table 1 all the variables had $\alpha$ greater than 0.7 while the overall reliability was 0.792 which confirmed that scale used in questionnaire construction was reliable.

\section{Response Rate}

Out of the four hundred (400) teachers who were sampled, two hundred and ninety-eight (298) responded to the questionnaires that were administered. This gave a response rate of $74.5 \%$ which according to Mugenda and Mugenda (2003) is satisfactory to conduct data analysis and interpretation of the findings.

\section{Descriptive Analysis}

The study sought to establish the mediating effect of employee engagement in the relationship between HRM Practices and turnover intentions and therefore respondents were asked to indicate 
INTERNATIONAL JOURNAL OF ACADEMIC RESEARCH IN BUSINESS AND SOCIAL SCIENCES Vol. 10, No. 9, 2020, E-ISSN: 2222-6990 @ 2020 HRMARS

their level of agreement or otherwise on various aspects of Employee engagement and 4 HRM Practices namely compensation, career development, performance appraisal and training. The Likert scale was based on a scale of 1-5. The results are presented in table 2

Table 2 Results for Descriptive Analysis

\begin{tabular}{|l|l|l|}
\hline HRM Practices & Aggregate Mean & Standard Deviation \\
\hline Compensation & 2.17 & 1.02 \\
\hline Career Development & 2.69 & 1.15 \\
\hline Performance Appraisal & 2.69 & 1.09 \\
\hline Training & 2.84 & 1.18 \\
\hline Employee Engagement & 3.56 & 1.04 \\
\hline
\end{tabular}

From table 2 in regard to compensation, majority of the respondents disagreed that the employer had done enough to enhance better compensation for their various responsibilities and this was indicated by an aggregate score of 2.17. A standard deviation of 1.02 was an indication that the respondents had less varied views concerning compensation. These results concurs with findings by Ekabu (2019) which established that majority of teachers were dissatisfied with various aspects of remuneration they get from the employer. In relation to career development the respondents were neutral that various activities and programs by the employer and supervisors enhanced furtherance of their careers as confirmed by an aggregate mean score of 2.69 and a standard deviation of 1.15.

Performance appraisal had also an aggregate score of 2.69 and a standard deviation of 1.09 . This implied that respondents were also neutral on various aspects of the appraisal system. These findings concur with study by Manthi et al. (2018) which found that teachers were neutral on various aspects of performance management with a mean of 2.9 and a standard deviation of 1.12 The respondents were also neutral on various issues concerning training represented by an aggregate score of 2.84 and a standard deviation of 1.18 .

It has been argued that employees' behaviors and attitudes are influenced by the way HRM practices are perceived by employees such that when employees positively view HRM practices then they will have no thought of leaving the organization (Nishii and Wright, 2008). It is therefore necessary to correct the employees' perception on HRM practices in order to ensure increased intention to stay.

The aggregate mean score for Employee engagement was 3.56 indicating that the teachers were engaged with their work. A standard deviation of 1.04 implies that the views of the respondents were not much varied. Since from these findings it is evident that most respondents were engaged in their work it is necessary for TSC to ensure this continues in order to help reduce intentions to leave by teachers. Nurita, P'awan and Hansaram (2013) posit that engagement is enhanced by HRM practices through effective HRM. According to the JD-R Model resources give energy to the employees, make them persistent, and increase concentration on their efforts. Koyuncu et al. (2006) also assert that employees find it hard to leave their current job when they are engaged because they become identified with their job.

Turnover intentions which was the dependent variable of the study was considered as a binary variable. The respondents were asked whether they will leave their current job if they get a better job. The findings are presented in table 3. 
INTERNATIONAL JOURNAL OF ACADEMIC RESEARCH IN BUSINESS AND SOCIAL SCIENCES

Vol. 10, No. 9, 2020, E-ISSN: 2222-6990 @ 2020 HRMARS

Table 3: Response on Turnover Intentions

\begin{tabular}{lll}
\hline $\begin{array}{l}\text { Will leave the current job } \\
\text { if I get a better job }\end{array}$ & Frequency & Percentage \\
\hline No & 51 & 17.1 \\
Yes & 247 & 82.9 \\
Total & $\mathbf{2 9 8}$ & $\mathbf{1 0 0}$ \\
\hline
\end{tabular}

As shown in table 3, 82.9\% (247) of the teachers indicated they intend to leave. However, $17.1 \%$ (51) of them intend to stay. The findings provide a clear indication that those teachers in public secondary schools in Murang'a County Kenya who were the respondents of the study that intend to leave are more than those that want to stay. In line with SET it has been suggested that when organization implements better HRM practices employees will reciprocate to the organization through positive behaviour such as intention to stay (Kinnie et al., 2005). There is therefore need to address high intention to leave by teachers through improving the teachers' perception of HRM practices in order to avoid compromising quality of education.

\section{Test of Hypothesis}

The current study used Logistic regressions to test the influence of the independent variables on the mediating and the dependent variable. However, so as to meet the basic assumptions of logistic regressions it was necessary to carry out diagnostic tests before testing the research hypothesis in order to accurately estimate the regression model. According to Peter and Ahmed (2018), it is necessary to conduct these tests in order to better the power of the model. The tests of multicollinearity, influential values as well as independence of errors were done and the results indicated all the basic assumptions were met. This made it possible to carry out the logistic regression analysis.

In order to test the hypothesis that employee engagement does not mediate the relationship between HRM practices and turnover intentions of teachers in public secondary schools in Murang'a County, Kenya, this study used the three models that were estimated based on the recommendation by Baron and Kenny (1986).

\section{Step One: Relationship between HRM Practices and Turnover Intentions}

The study fitted a base model to establish whether HRM practices predicted turnover intentions of teachers in public secondary schools in Murang' a County, Kenya. Table 4 presents the results.

Table 4: Step One in Testing Mediating Effect of Employee Engagement

\begin{tabular}{lllllllll}
\hline Variable & B & S.E. & Wald & df & Sig. & Exp(B) & \multicolumn{2}{c}{ 95\% C.I. for EXP(B) } \\
& & & & & & & Lower & Upper \\
\hline HRM Practices & 0.012 & 0.002 & 23.993 & 1 & 0.000 & 1.012 & 1.007 & 1.017 \\
Constant & -2.423 & 0.25 & 94.198 & 1 & 0.000 & 0.089 & &
\end{tabular}


INTERNATIONAL JOURNAL OF ACADEMIC RESEARCH IN BUSINESS AND SOCIAL SCIENCES

Vol. 10, No. 9, 2020, E-ISSN: 2222-6990 @ 2020 HRMARS

Model $X^{2} 27.509, P<0.052,-2 \log$ likelihood 245.274, Nagelkerke $R$ Square $=0.166$

\section{Source: Research Data (2019)}

The results in table 4 show that the model is significant and fit quite well at $\mathrm{P}<0.05$ with pseudo $\mathrm{R}^{2}$ value (Nagelkerke $R$ Square) of 0.166 implying the Composite HRM Practices account for $16.6 \%$ variations in turnover intentions. Further, the $p$-value of HRM practice is less than 0.05 while the odd ratio, exp (B), is greater than 1 implying that HRM significantly predicts turnover intentions.

Logit $(Y)=-2.423+0.012 X+\varepsilon$ Model 1

Where: $Y=$ Turnover Intention; $X=$ HRM Practice

\section{Step Two: HRM Practices Predicting Employee Engagement}

The second model was fitted to test whether HRM practices (Compensation, Performance appraisal, Career development and Training) predicted the mediator (Employee engagement). The results are as shown in table 4

Table 5: Step Two in Testing Mediating Effect of Employee Engagement

\begin{tabular}{llllll}
\hline \multicolumn{7}{l}{$\begin{array}{l}\text { Unstandardized } \\
\text { Coefficients }\end{array}$} & \multicolumn{2}{l}{$\begin{array}{l}\text { Standardized } \\
\text { Coefficients } \\
\text { B }\end{array}$} & Std. Error & Beta & t & Sig. \\
\hline (Constant) & 3.263 & 0.06 & & 54.751 & 0.000 \\
HRM Practices & 0.005 & 0.001 & 0.378 & 7.025 & 0.000 \\
$\mathrm{R}^{2}=0.143$ & & & & & \\
Sig $=0.000$ & & & & & \\
\hline
\end{tabular}

Dependent Variable: Employee Engagement

The results as shown in table 5 indicate that $R^{2}$ is 0.143 implying that HRM practices predict $14.3 \%$ of the variation in employee engagement with the model significant at $5 \%$ level of significance. Further, $\beta=0.005$ while $P<0.005$ which implies that employee engagement is significantly influenced by HRM practices of the subjects of the study.

$\mathrm{M}=3.263+0.005 X+\varepsilon$ Model 2

Where: $\mathrm{M}=$ Employee Engagement; $\mathrm{X}=$ HRM practices

\section{Step Three: HRM Practices and Employee Engagement Predicting Turnover Intention}

The final model was fitted to test whether HRM practices predicted turnover intentions in the presence of employee engagement (mediator). The following model was used to establish whether there is complete, partial or no mediation between the independent variable and dependent variable:

Logit $(Y)=\beta_{0}+\beta_{1} X+\beta_{2} M+\varepsilon$

Where: $Y=$ Turnover intention; $X=$ Composite of HRM practices; $M=$ Employee engagement . The results are presented in table 6.

Table 6: Step Three in Testing Mediating Effect of Employee Engagement 
INTERNATIONAL JOURNAL OF ACADEMIC RESEARCH IN BUSINESS AND SOCIAL SCIENCES Vol. 10, No. 9, 2020, E-ISSN: 2222-6990 @ 2020 HRMARS

\begin{tabular}{|c|c|c|c|c|c|c|c|c|}
\hline & \multirow[t]{2}{*}{ B } & \multirow[t]{2}{*}{ S.E. } & \multirow[t]{2}{*}{ Wald } & \multirow[t]{2}{*}{ df } & \multirow[t]{2}{*}{ Sig. } & \multirow[t]{2}{*}{$\operatorname{Exp}(B)$} & \multicolumn{2}{|c|}{ 95\% C.I. for EXP(B) } \\
\hline & & & & & & & Lower & Upper \\
\hline HRM Practices & 0.010 & 0.003 & 14.558 & 1 & 0.000 & 1.01 & 1.005 & 1.015 \\
\hline Employee Engagement & 0.555 & 0.253 & 4.834 & 1 & 0.028 & 1.743 & 1.062 & 2.859 \\
\hline Constant & -4.332 & 0.94 & 21.26 & 1 & 0.000 & 0.013 & & \\
\hline \multicolumn{9}{|l|}{ Model X' 32.583, } \\
\hline \multicolumn{9}{|c|}{-2 Log likelihood 240.201; Nagelkerke R Square =0.169 } \\
\hline
\end{tabular}

The results as shown in table 6 indicate that the model is significant at $P<0.05$ with Nagelkerke $R$ Square of 0.169 which means employee engagement explains $16.9 \%$ of variations in turnover intentions. The coefficient of HRM practices (0.010) is less than the corresponding value without the mediator (0.012) while the $p$-value is less than 0.05 . The $p$-value of employee engagement is also significant. The -2 Log likelihood has reduced from 245.274 (table 5) to 240.201 indicating the model improvement. The results imply that HRM practices and employee engagement significantly predicted turnover intentions.

$\operatorname{Logit}(Y)=-4.332+0.010 X+0.555 M+\varepsilon$ Model 3

Where $Y=$ Turnover Intention; $X=$ HRM Practices; $M=$ Employee Engagement

A summary of mediation test of employee engagement on the relationship between HRM practices and turnover intentions of teachers in public secondary schools in Murang'a County, Kenya is presented in table 7

Table 7: Summary of Mediation Test of Employee Engagement

\begin{tabular}{llll}
\hline Model & Step & Result & Conclusion \\
\hline Logit $(Y)=-2.423+0.012 X+\varepsilon$ & 1 & $\mathrm{P}<0.05$ & Significant \\
$M=3.263+0.005 X$ & 2 & $\mathrm{p}<0.05$ & Significant \\
Logit $(Y)=-4.332+0.010 X+0.555 M+\varepsilon$ & 3 & $\mathrm{p}<0.05$ & Significant \\
\hline
\end{tabular}

Based on the results in table 7, the effect of HRM practices on turnover intentions of public secondary school teachers in Murang'a County remained significant when employee engagement was introduced to the model. This was evidence of partial mediation (Baron \& Kenny, 1986). The study therefore concluded that employee engagement partially mediated the relationship between HRM practices and turnover intentions of public secondary school teachers in Murang'a County, Kenya.

The study therefore rejected $\mathrm{H}_{0}$ : Employee engagement does not mediate the relationship between HRM practices and turnover intentions of teachers in public secondary schools in Murang'a County, Kenya. The findings of the study are consistent with Hakanen et al. (2006); Chughtai (2013) which confirmed the mediating role of employee engagement between HRM practices and turnover intentions. This implies that organizations are more likely to experience low intention to leave when employees are more engaged as a result of HRM practices being effectively implemented. This therefore calls for teachers' employer to put in place HRM practices that would increase teachers' engagement levels so as to increase intention to stay. 


\section{Conclusions}

Based on the results of the study, the following conclusions were made. Teachers are not satisfied on various aspects of compensation offered by the employer. However, they were neutral on various aspects of performance appraisal, career development and training by the employer. The study also concluded that HRM Practices influences turnover intentions of teachers and therefore there is need to improve the HRM practices in order to increase intention to stay. Lastly, teachers in public secondary in Murang'a County are engaged and employee engagement partially mediates the relationship between HRM practices and turnover intentions. This implies that employee engagement plays a part in enhancing effectiveness of HRM practices in improving intention to stay of teachers in public secondary schools in Murang'a County. That is, more engaged teachers utilized HRM practices that enhanced their intentions to stay.

This study recommends to the organizations / TSC that the focus should not only be on the actual implementation of HRM practices but also on how employees perceive HRM practices so as to incorporate their employees' expectations in order to be able to increase employee engagement and lower intentions to leave. In this regard the TSC should implement a participatory approach system before and during implementation of HRM practices and policies so that the employer will have feedback which can be used to improve and implement the HRM Practices and policies. This will not only increase engagement and intention to stay but also help the teachers to own the policies and practices and thus enhancing implementation and achievement of the intended goals.

This study therefore contributes to the HRM literature by providing evidence that employee engagement mediates the relationship between HRM practices and employees' turnover intentions. It thus supports the assertion that employee engagement has a role to play in the retention of employees in organizations. It therefore provides a challenge to Kenyan employers to provide working environments that will enhance employee engagement in order to boost employee retention and consequently leading to achievement of organizational goals,

The study also contributes to HRM conceptual and empirical literature by considering turnover intentions as a dichotomous variable as opposed to a continuous variable as it has been the case with the majority of turnover intentions studies. This allowed the use of logistic regression which provides a basis which can be used to build turnover intentions prediction models.

From the logistic regression results, Composite HRM practices accounted for $16.6 \%$ variation in turnover intentions. This could be explained by the fact that the study only considered four HRM Practices. This implies that there are other practices responsible for the variance in turnover intentions which were not considered in this study. The study recommends that future studies should focus in considering other factors that account in variation of turnover intentions of teachers in public secondary schools. In this study total effect of employee engagement was considered in the mediation test. Other studies can consider the mediating effect of the individual components of employee engagement in turnover intentions research. Other studies should also focus on other sectors, both public and private, as this study predominantly focused on the education sector. Since this was a cross sectional study other studies can consider a longitudinal study.

\section{Data Availability Statement}

The data that support the findings of this study are available in Zenedo. at http://doi.org/ 10.5281/zenedo/3997305 
INTERNATIONAL JOURNAL OF ACADEMIC RESEARCH IN BUSINESS AND SOCIAL SCIENCES Vol. 10, No. 9, 2020, E-ISSN: 2222-6990 @ 2020 HRMARS

\section{References}

Allensworth, E., Poniscia, K. S., \& Mazenzo, C. (2009). The Schools Teachers Leave: Teacher mobility in Chicago Public schools. Chicago: Consortium on Chicago school Research-University Chicago.

Armstrong, M., \& Stephen, T. (2014). Armstrong's Handbook of Human Resource Management Practice (13th ed.). London: Kogan Page Limited.

Banken, H. H. M. (2010). Do HR practices reduce turnover intentions and is this relation mediated by employee engagement. (Unpublished Masters thesis). Tilburg University.

Bhat, Z. F. (2014). HR practices and employee turnover intentions. A correlational analysis. Global Journal for Research Analysis International, 3 (7), 171-173.

Cheche, S. G., Muathe, S. M. A., \& Maina, S. M. (2017). Employee engagement, organisation commitment and performance of selected State Corporation in Kenya. European Scientific Journal, 13(31), 317-327. DOI:10. 19044/esj.2017.v13n31p317

Chughtai, T. A. (2013). Role of HR practices in turnover intentions with the mediating effect of employee engagement. Wseas Transactions on Business and Economics, (2), 10, 97-103.

Cropanzano, R., \& Mitchell, M. S. (2005). Social Exchange Theory: An interdisciplinary review. Journal of Management, 31, $874-900$.

Curry, E. J., \& Hill, R. A. C. (2012). What are the reasons for high turnover in nursing? A discussion, presumed causal factors and remedies. International journal of Nursing Studies, 49(9), 11801189.

Eisenberger, R., Huntington, R., Hutchinson, S., \& Sowa, D. (1986). Perceived organizational support. Journal of Applied Psychology, 71, (3), 500-507.

Ekabu, P. K. (2019). The Level of Remuneration and Turnover Intention of Public Secondary School Teachers in Meru County: A Mixed Method Study. European Scientific Journal, ESJ, 15(13), 1. https://doi.org/10.19044/esj.2019.v15n13p

Field, A. P. (2009). .Discovering statistics using SPSS, 2nd edition. London: Sage.

Firebaugh, G. (2008). Use panel data to study individual change and repeated cross-section data to study social change: In the seven rules for Social Research (Chapter 6). Princeton, NJ: Princeton University Press.

Fleming, J. H., \& Asplund, J. (2007). Human sigma. New York: Gallup press.

Gichohi, P. M. (2014). The role of employee engagement in revitalizing creativity and innovation at the workforce: A survey of selected libraries in Meru County, Kenya, Library, philosophy and practice, (e-journal): paper 1171. http://digitalcommons unl.edu/libphilpract/1171.

Hakanen, J. J., Bakker, A. B., \& Schaufeli, W. B. (2006). Burnout and work engagement among teachers. Journal of School Psychology, 43, 495-513.

Kaur, B., Mohindru., \& Pankaj. (2013). Antecedents of turnover intentions: A Literature Review. Global Journal of Management and Business Studies, 3(10), 1219-1230.

Kinnie, W., Hutchinson, S., Purcell, J., Rayton, B., \& Swart, J. (2005). Satisfaction of HR practices and commitment to the organisation: why size does not fit all. Human Resources Management Journal, 15(4), 9-29.

Kothari, C. R. (2004). Methods and techniques: Research methodology, (2nd ed.). New Delhi: New Age International Publishers Ltd.

Koyuncu, M., Burke, R., J., \& Fiksenbaum, L. (2006). Work engagement among women managers \& professionals in a Turkish Bank. Equal Opportunities International, 25, 299 - 310. 
INTERNATIONAL JOURNAL OF ACADEMIC RESEARCH IN BUSINESS AND SOCIAL SCIENCES

Vol. 10, No. 9, 2020, E-ISSN: 2222-6990 @ 2020 HRMARS

Krishman, S. K., \& Singh, M. (2010). Outcomes of intentions to quit of Judean Professionals. Human Resource Management, 49(3):28-36.

Kular, S., Gatenby, M., Rees C. M., Soane, E., \& Truss, K. (2008). Employee engagement: A literature review. Working paper series. Kingston University.

Lockwood, N. R. ( 2007). Leveraging employee engagement for a competitive advantage, SHRM Research Quarterly. Alexandria, VA: SHRM Foundation. Available at:http://www.shrm.org/research/articles/articles/documents/07marresearchquarterly.pdf

Llorens, S., Bakker, A. B., Schaufeli, W., \& Salanova, M. (2006). Testing the robustness of the Job Demands-Resources model. International Journal of Stress Management, 13(3), 378-391.

Manthi, A. K., Kilika, J. M., \& Kimencu, L. (2018). How do human resource management practices predict employee Turnover Intentions: An empirical survey of teacher training colleges in Kenya. International Journal of Business Admnistration. 9 (4), 201-213.

Muathe, S. M. A. (2010). The determinants of adoption of information and communication technology by small and medium enterprises within the health sector in Nairobi, Kenya. (Unpublished Ph.D thesis), Kenyatta University.

Mugenda, O. M., \& Mugenda, A. (2003). Research methods: Qualitative and quantitative approaches. Nairobi: ACTS Press.

Nurita, J., Pa'wan, F., \& Hansaram, R. M. K. (2013) HR practices and turnover intention: the mediating roles of organizational commitment and organizational engagement in a selected region in Malaysia. The International Journal of Human Resource Management, 24 (15). 3002-3019. DOI: 10.1080/09585192.2013.763841.

Park, J., \& Kim, T. (2009). Do types of organizational culture matter in nurse job satisfaction and turnover intention? Leadership and Health Sciences, 22, (1) 20-28.

Press, S. J., \& Wilson, S. (2007). Choosing between logistic regression and discriminant analysis. Journal of the American Statistical Association, 73, 699-705.

Perez, M. (2008). Turnover intent. (Unpublished Diploma thesis). University of Zurich.

Saks, A. M. (2006). Antecedents and consequences of employee engagement. Journal of Managerial Psychology, 21(7), 600-619.

Schaufeli, W. B. (2013). What is engagement? In C. Truss, K. Alfes, R. Delbridge, A. Shantz, \& E. Soane(Eds.), Employee Engagement in Theory and Practice. London: Routledge.

Schaufeli, W. B., \& Bakker, A. B. (2004). Job demands, job resources, and their relationship with burnout and engagement: A multi-sample study. Journal of Organizational Behavior, 25, 293315.

Schaufeli, W. B., Bakker, A. B., \& Salanova, M. (2006). The Measurement of work engagement with a short questionnaire: A Cross-National Study. Educational and Psychological Measurement, 66(4), 701-716. https://doi.org/10.1177/0013164405282471.

Schaufeli, W. B., \& Salanova, M. (2008). Enhancing work engagement through the management of human resources. In K. Näswall, J. Hellgren \& M. Sverke (Eds.), The Individual in the Changing Working Life (pp. 380-402). Cambridge: Cambridge University Press.

Shuck, M. B., \& Wollard, K. K. (2009). A historical perspective of employee engagement: An emerging definition. In M.S. Plakhotnik, S.M. Nielsen, \& D.M. Pane (eds), Proceedings of the Eighth Annual College of Education \& GSN Research Conference, (133-139). Florida International University. http:// coeweb.fiu.edu/research _ conference. 
INTERNATIONAL JOURNAL OF ACADEMIC RESEARCH IN BUSINESS AND SOCIAL SCIENCES

Vol. 10, No. 9, 2020, E-ISSN: 2222-6990 @ 2020 HRMARS

Soane, E. Truss, C., Alfes, K., Shantz, A., Rees, C., \& Gatenby, M. (2012). Development and new measure of employee engagement: The ISA Engagement scale. Human Resource Development International, 15(5), 529-547.

Stairs, M., \& Galpin, M. (2010) Positive engagement: from employee engagement to workplace happiness, in (eds) P A Linley, S Harrington and N Garcea, The Oxford Handbook of Positive Psychology and Work, New York, Oxford University Press.

Sweet, S. A., \& Grace-Martin, K. A. (2012). Data analysis with SPSS: A first course in applied statistics. ( $4^{\text {th }}$ Ed.) Pearson.

Takase, M. (2010). A concept analysis of turnover intention: Implication for nursing management. Collegian, 17, 3-12.

Tarmizi, A. N. (2008). Quality work life and turnover intentions: The mediating effect of career and organizational commitment, (Masters thesis). Business Administration, USM. Retrieved on 30/10/2017, URL: http://eprints,um.my/id/eprint/25416

Verhees, J. M. A. (2012). The relationship between training and employees' turnover intentions and role of organizational commitment. (Unpublished Masters thesis), Tilburg university, Netherlands.

Waititu, G. M. (2013). An analysis of factors influencing turnover of teachers in public high schools in Limuru District, Kenya. Unpublished Masters Thesis, Kenyatta University.

Yamane, T. (1967). Statistics: An introduction analysis (2 ${ }^{\text {nd }}$ ed.), New York: Harper and Row. 